\title{
The Processes of Law Making in a Presidential System of Government: The Nigerian Experience
}

\author{
Paul Y. Mbaya ${ }^{1}$, Charas Madu Tella ${ }^{2} \&$ Raphael Audu Adole ${ }^{3}$ \\ ${ }^{1}$ Department of Public Administration, University of Maiduguri, Borno State, Nigeria \\ ${ }^{2}$ Department of General Studies, University of Maiduguri, Nigeria \\ ${ }^{3}$ Department of Public Administration, University of Maiduguri, Nigeria \\ Correspondence: Paul Y. Mbaya, Department of Public Administration, University of Maiduguri, Borno State, \\ Nigeria. Tel: 234-802-454-6715/234-803-131-2796. E-mail: pymbaya@gmail.com
}

Received: October 22, 2012 Accepted: December 12, 2012 Online Published: January 28, 2013

doi:10.5539/ass.v9n2p106 URL: http://dx.doi.org/10.5539/ass.v9n2p106

\begin{abstract}
No modern society can exist without a system of laws. The institution of law is therefore crucial to the social organization of human beings. A modern society is a far -cry from the state of nature which is often described as a lawless society. In a presidential system of government, the process a bill goes through before becoming a law is essentially the same. Countries, however, have minor differences. The processes of law making generally requires a long period of deliberation and consideration of the many interests and implications of the bill. A bill must pass into various stages and readings before it can be passed to law. The paper discusses these processes of law making with particular reference to Nigeria and argues that people's participation in these processes are very significance in facilitating good governance and better service delivery in Nigeria. The paper recommended among others that all bills should be open to public inputs, suggestions, comments and debate to attract public acceptance by Nigerians.
\end{abstract}

Keywords: a bill and a law, types of laws in Nigeria, sources of bills, processes of law making

\section{Introduction}

The National Assembly in Nigeria is responsible for making laws. The Nigerian system is based on the process developed in the United States of America commonly called the Presidential System. In this System, the National Assembly (the legislative branch) operate on a bicameral system, which means that they have two houses. This is usually divided into a lower and upper house and both houses members came in through elections. However, at the federal level, the lower house is known as the House of Representatives while the upper house is known as the Senate. In most cases, bills are introduced into the lower house of parliament (Brich, 1983). This is because the government usually has a majority in the lower house.

The Constitution of the Federal Republic of Nigeria is the most powerful law of the land (Oluyede, 1988). The introductory part of the 1979 Constitution speaks on the supremacy of the Constitution. It states "this Constitution is supreme and its provision shall have binding force on all authorities and persons throughout the Federal Republic in Nigeria". In another section it says "if any other law is inconsistent with the provisions of this Constitution, this Constitution shall prevail, and that other law shall to the extent of the inconsistency be void". The importance of this is that no law must go against the Constitution. Any law that violates the Constitution is null and void - it is not valid or legal and cannot be enforced (Equal Justice, 2001).

Deciding whether a law is consistent with the Constitution is the duty of the courts. In other words, only the courts can decide whether a law is constitutional or not (Egi, 1997). So if someone feels that a law is not in line with the Constitution, he has the right to go to court of law and seek redress, or to have the law declared unconstitutional (Cardozo, 1957). In this respect, the laws being made by the National Assembly must be in agreement with the constitution. The paper examines the importance of participation, consultation and interaction with members of the society in the processes of law making. However, before discussing these processes, let look at conceptual issues and some of these laws in Nigeria that must be in agreement with the constitution. That is to say that, if any of these laws is inconsistent with the provisions of the Constitution, the Constitution shall prevail, and that other law shall to the extent of the inconsistency be void. 


\section{Conceptual Issues}

\subsection{A Bill and Law}

No modern society can exist without a system of laws. The institution of law is therefore crucial to the social organization of human beings (Ujo, 2002). Before an item of legislation becomes a law, it exists as a bill proposed to National Assembly (William, 2006). A bill is a proposal for a new law, or a proposal to change an existing law (Hart, 1961). A law is a rule or set of rules made by the Parliament( Proposals for new legislation, or amendments to legislation, can come from many different sources, including the Cabinet of the government, members of opposition parties, or through suggested amendments to existing laws received from bodies like the Federal Executive Council or the Federal Civil Service Commission.

\subsection{Presidential System}

Separation of powers is a doctrine of the presidential system of government whereby government is divided into three branches, namely the Executive, Legislature and Judiciary. The essence is that each branch is not permitted to encroach on the domain or exercise of powers of another branch. Separation of powers means therefore that the functions of lawmaking, execution and adjudication are rested in separate agencies operating with separate personnel and procedure. The essence of the division of powers can be better appreciated when viewed from Locke's perspective (Johari, 2003). He thought that it was convenient to confer legislative and executive powers on different organs of government as the legislature can act quickly and at intervals while the executive must constantly be at work. Montesquieu based on the study of Locke's work was concerned with the preservation of political liberty as follows: Political liberty is to be found only when there is no abuse of power. But constant experience shows us that every man invested with power is liable to abuse it, and to carry his authority as far as it will go (Ali, 2001).

To control this abuse of power, it is necessary that one power should be a check on another...when the legislative and executive powers are united in the same person or body...there can be no liberty...Again, there is no liberty if judicial power is not separated from legislative and executive...There would be an end of everything if the same person or body, whether of nobles or of the people, were to exercise all three powers. This implies that neither the legislature, nor the executive nor the judiciary should exercise the whole or part of another's powers to guarantee the fundamental human rights of citizens (Almond and Powell, 1966).

\subsection{Types of Laws in Nigeria}

1)Constitution

The Constitution is the number one law in Nigeria. It is the supreme law of the land that guides the process of governance. It sets forth the duties and obligations of the different branches of government. It also delineates the fundamental human rights and obligations of citizens. Some of these basic rights and liberties are contained in the 1999 constitution section 33-44 of chapter IV: rights to life, to dignity of human person, to personal liberty, to fair hearing, to private and family life, to freedom of thought, to conscience and religion, to freedom of expression and the press, to peaceful assembly and association, to freedom of movement, to freedom from discrimination, to acquire and own immovable property anywhere in Nigeria; and compulsory acquisition of property. Government should not deprive its citizens from enjoying them. Another name by which constitution is known is the Grundnorm, or the ultimate and the highest form of law, from which all other laws derive (Ali, 2001). No law may contravene any of its provisions. Any other law that goes against any provision of the Constitution is void to the extent of such inconsistencies.

\section{2)Statutes}

Statutes are laws passed by the National Assembly (Jackses, 1979). The National Assembly has the power to make new laws or amend existing ones. It can also repeal or amend decrees that are obnoxious. Such amendments can cover laws made during the colonial era or those periods when Nigeria operated as a democracy between 1960 and 1966 and 1979 and 1983. Parts of the statutes are the decrees passed under the different Military administrations the country has had in the past. Some of these decrees that have been gazetted are also referred to as "Acts" in the laws of the Federation of Nigeria (Equal Justice, 2001).

\section{3)Common Law}

These are laws inherited from the British during colonial period and because Nigeria is a former colony of Britain, it adopted the common law tradition of Britain.

4)Penal Code

The Penal Code is in force among the Northern States and the Federal Capital Territory, Abuja and it was 
adopted substantially from the Sharia (Islamic Legal System). It consists of personal laws such as the law of inheritance, marriage and a few criminal laws whose punishments are modified as against that which Islam prescribes. For example, stoning to death for adultery and flogging for fornication as stipulated in Islamic law, are modified in their application under the Penal Code. Just like the customary law, the Penal Code regulates the concept of crime and punishment together with the criminal procedure code. According to Equal Justice (2001), this law is inferior to the Constitution and as such no aspect of the law must go against the Constitution.

\section{5)Criminal Code}

The Criminal Code is operated among the Southern states of the country. The Criminal Code contains about four hundred (400) criminal offences and their punishments. Unlike the Penal Code which incorporates Islamic law, the Criminal Code is fashioned after the British law. The Criminal Code and the Criminal Procedure Act prescribes crimes and punishment in these states. Both the Criminal Code and the Penal code form part of our statutes.

\section{6) Customary Law}

The Nigeria Customary Law system is the law of the different communities in the country. Basically, this law is flexible, and every community has its own law, which is not written down. The interpretation and application of these laws depend on the changing conditions of the people, chiefs and traditional leaders. Customary Law as the name implies, is derived from the customs and culture of the people it governs. There are several Customary Courts presided over by community leaders and traditional chiefs. The law can, however, be changed or modified by the Constitution of the country if any of its aspect goes against the Constitution. Customary Law specifically deals with such things as, marriage, divorce, inheritance, land ownership etc.

\section{Theoretical Frame-Work for Analysis}

Citizen participation is a process which provides private individuals an opportunity to influence public decisions and has long been a component of the democratic decisions-making process. Public involvement is a means to ensure that citizens have a direct voice in public decisions. Being used to indicate a process through which citizens have a voice in public policy decisions (Mbaya, 2007). The public involvement and input in planning and policy implementation is sought through keeping open the communication channels between the public and the governmental apparatus and as well as through efforts to create awareness and interest in governmental activities and programmes. Some of the methods include public hearings, referenda, public discussions, public information of governmental plans and alternatives, provision of avenue for public objections and reactions to government on her activities and propaganda/public enlightenment programmes and actions. It is through these medium which the interest, awareness and participation of the relevant public such as interest groups and communities could be encouraged. This channel also creates opportunities for the relevant publics to express themselves on various issues. The citizen participation approach helps in educating the public on government plans, programmes and activities. It also provides information on the preferences, perceptions and needs of the public, particularly those most affected by government programmes. It furthermore enables the determination of citizen perceptions of the effectiveness of public services and citizen opinion and attitudes to government programmes.

This presupposes that this approach will enable the needs, concerns, problems and interests of the differing groups in society to be expressed and considered. It also enhances equity because it enables government to react to and balance different interests and problems of various groups. It furthermore enhances public mobilization and thus commitment to programmes, which could raise public support, confidence and possibilities of programme success as concluded by Ikelegbe (1996). Similarly, according to Mbaya (2009), the processes of law making generally requires a long period of deliberations and considerations of the many interests and implications of the bill. For example, the sources of a bill, the stages it pass through and up the time the president signs it to become law; people's participation in these processes are very significance in the following ways: Members of the public can contribute among these sources of a bill: Executive bill, Members bill and Private member bills. When the public observed that there is a need for a law to regulate a particular institution of government to ensure good governance they can initiate a bill through the Private Member bills. These are bills that are initiated by an individual or a group of people or an organization. However, this bill can only be introduced in the Senate or House by a member.

The electorates could also participate in legislative process through the constituency office (Pound, 1997). They are expected to bring to the notice of their senator or house member their inputs, observations and suggestions on how the community members can be served better in terms of law making and better service delivery through the constituency offices. This pre-supposes that the needs and the problems of the community can be collected in 
these offices that will help the legislators to make better laws and policies that will facilitate good governance. Moreso, their inputs at the Committee stage: The essence of the committee stage is to look at the bill more closely in order to improve the quality of the bill to serve the public better. The public are expected to contribute their inputs through position papers, seminars, in media houses, etc to assist the legislators to make good laws. This is possible under the bills that are open to public for discussions and deliberations. Similarly, they can equally participate by electing credible representatives: The constitutions of the Federal Republic of Nigeria especially the 1999 constitution mandates the electorates to elect both the executives and the legislators at Local, State and Federal levels as their representatives. This is one of the beauties of democracy to be able to participate in electing who to represent them at all levels.

This pre-supposes that only credible representatives can be elected in these positions. If this happens there shall be effective service delivery (dividends of democracy) and good governance in Nigeria. However, if they sell their votes and elected bad representatives, our democratization process would be reduced to only voting without choosing which cannot guarantee good governance; and finally by voicing through the NGos: The public can also participate in legislative process through the various non-governmental organizations especially the Community Based Organizations(CBOs).The CBOs are more closer to the people, they know their problems and what can be done to improve their living standards. They can easily take up the matter and discuss with their members on the possibilities of improving their living conditions in terms of law making, policies, and programmes.

\section{Sources of Bills}

There are three (3) major sources of bill. These are as follows:

1) Executive Bills

The most common type of bills introduced into the Parliament is 'executive bills', which deal with matters of general public interest (Jennings, 1960). Public bills may be introduced by either a minister or secretary to the Federal Government on behalf of the government. A number of bills are often initiated by the executive branch of government. This is due to the fact that the Executive comprises the President and the ministers. Policies must be enacted to allow them to carryout their responsibilities. Hence, any bill initiated by a minister or the president himself falls under the category of an Executive Bill. Money Bills also falls under this category. Money or 'Appropriation' bills are public bills which set a tax or propose the spending of money for a particular purpose. Money bills follow the same passage through both Houses as other bills. Basically, government bills stem from party policies, pressure from community groups, the media or public opinion, advice from government departments or even because of court decisions. When the Government decides that laws are needed, the minister concerned submits a proposal to the Federal Executive Council (FEC) (a meeting of all ministers) for approval. A draft bill is prepared by the Parliamentary Counsel acting under instructions from the minister and the minister's department (Dicey, 1965). This draft may go through several revisions before being finally prepared for introduction to the National Assembly.

\section{2) Members bills}

The primary functions of legislatures are to make laws. So, any bill introduced by a Senator or a member of the House of Representatives falls under this category. The idea for a bill may come from a party manifesto or a promise made during the members' campaign for election.

\section{3) A private member bills}

Private members can also initiate a bill in response to pressure from their constituents, community groups, the media or public opinion. In short, these are bills that are initiated by an individual or a group of people or organization. However, a bill initiated by an individual or a group of people can only be introduced in the Senate or House by a member. After community consultation, the member introduces the bill into the Parliament.

\section{Processes of Law Making in Nigerian National Assembly}

In a presidential system of government, the process a bill goes through before becoming a law is essentially the same. Countries, however, have minor differences. The processes of law making generally requires a long period of deliberation and consideration of the many interests and implications of the bill. A summary of the processes and the tasks involved are discussed below. A bill must pass into four (4) stages and receive three (3) readings before it can be passed into law. However, this is not applicable to all circumstances and bills. These stages takes place in both Houses:

1)Stage one-identification of the need for a bill, proposal stage 
2)Stage two: First reading (introduction of the Bill without debate)

3)Second reading (general debate)

4)Committee stage (detailed examination, debate and amendments)

5)Report stage (opportunity for further amendments)

6) Third reading (final chance for debate; amendments before the third reading is done)

7)Stage three: the Clerk and the clean copy of the bill

8) Stage four: the President

\subsection{Stage 1}

The first stage is the identification of the need for a bill. This bill can be a new one, introducing a new idea not yet covered by an existing law. It can also be an amendment to an existing law, which is thought to be inadequate either because of some changes in the policies of the government or changes in the society. The Anti-Corruption law passed by the National Assembly in 2000 for example, addresses corruption more than previous laws, which were found to be inadequate. It can also be that the existing law is considered to be infringing on another fundamental human right, that is, it goes against provisions of the constitution that guarantees a rights of Nigerian citizens. This is always the case with Military decrees.

A bill can be initiated by anybody but only a member of the House or the Senate can introduce it on the floor. A bill is like a proposal or an idea that has to be deliberated upon and passed into law by the National Assembly. Before a bill is introduced, all its financial implications must be calculated and attached. In other words, the amount that would be needed in executing specific aspects of the law when it is passed must be computed or calculated so as to know whether the government would be able to accommodate it in current or the future budget. For example, in passing the Niger Delta Development Commission (NDDC) bill, the government gave a breakdown of what it would take to make the commission function in terms of staff, transport, accommodation and other facilities that would assist or enhance the work of the commission. It also stated the sources of such funds the commission would receive. When a bill is prepared by the executive, it has to be forwarded to the Speaker of the House and the Senate President with a cover letter from the President or the Attorney General himself. All bills from the executive branch of government are always discussed concurrently (i.e. at the same time) in both the Senate and the House of Representatives.

All bills are numbered or marked according to their chamber of origin. For example, a bill from the House of Representatives is marked HB (House Bill) while the one from the senate is marked SB (Senate Bill). An executive bill is marked with "Executive" printed on the title page of the bill. It is printed tiny and to the right hand side of the page. All bills, whether from the Executive or member(s) of the House are to be forwarded to the speaker, while Bills from members of the senate are to be forwarded to the Senate President. The speaker or the Senate president then sends it to the Rules and Business Committee in the case of the House of Representatives and the Committee on Rules and Procedure in the case of the Senate. These committees then look at the bill to determine whether it meets all the standards in draft and presentation. If not, the bill will be forwarded to the Legal Department of the National Assembly for redrafting and further advice.

Executive bills are gazetted or published in the House/Senate Journal once, while those introduced by members are published three times before they can be presented to the House/senate for deliberations and consideration. The House Rules and Business Committee or the Senate Committee on Rules and Procedures is also expected to number bills and determine the day and the time they will be discussed in the House/Senate. All bills must receive three readings before they can be passed into law. The readings must be on different days except the House or the Senate may decide in certain cases to hear the three readings in a day. Examples of such a bill that might receive three readings in a day include the ones that are needed to enable the President take an urgent action, particularly on matters related to national security. In a situation where a bill is to be passed within a day, certain provisions of the House Rules must be suspended to enable immediate action.

\subsection{Stage 2}

\subsubsection{First Reading}

The member who wishes to propose the new law or legislative amendment introduces the bill to the House. This is known as the first reading. Only the title of the bill is read at the first reading, and copies are distributed for members of parliament to read (Stephen, 2005). The Clerk of the House/Senate usually does the reading of bills scheduled on the House/Senate Calendar (a schedule indicating the day and the time each bill will receive reading). He or she reads the short title of the bill for the first reading and then proceeds to "table" it. The word "table" is 
used to mean the action by which the Clerk places the bill on the table before the Speaker/Senate President. Normally, at this stage there is no debate on the bill on the floor of the House/Senate. The reading simply informs the members that a particular bill has been introduced and received. From here, the bill moves to the next stage.

\subsubsection{Second Reading}

In the second stage, known as the second reading, the member who introduced the bill explains the purpose of, and reasoning for, the proposed law. At this stage, members of the House may ask for further explanation as to the effect of the bill, its costs and the administrative arrangements for the proposed law. Amendments to the bill can also be proposed at this stage as put forward by Padfield (1976), which the members can then vote on the bill, and if it is passed, it proceeds to the third reading. This period is when debate occurs on the bill. It commences with a motion by the Senate or House Leader that the bill be read the second time, if it is an Executive Bill. The motion must be seconded (supported) by any of the other parties' leaders. When it is not seconded, the bill cannot be debated but in most cases, Executive bills are allowed, as a matter of courtesy to proceed to a second reading.

However, if the bill is by a Member of the House or the Senate, the sponsor of the bill would move the motion that it be read the second time. The motion must be seconded (supported) by another member of the House or Senate. Also, when a bill by a member cannot get the support of another member in the House or Senate, it cannot be debated and hence stands rejected. The person moving the motion, whether in the case of Executive or member bill, is expected to highlight the objectives, general principles and subject matter of the bill. He is also expected to state the benefits of the bill if passed into law. If the House agrees to the motion, the clerk will read the long title of the bill. Immediately after this, members must signify their intention to speak on the bill and therefore two things can occur at this stage:

1) The bill may receive the support of the majority of the House/Senate and be allowed to move to the next stage. Once it gets the needed support, it moves to the committee stage.

2) The bill may be "Negative" (killed) if it does not get the support of the majority of the House or senate Members. When a bill is killed, it is taken off the table and cannot be discussed until it is re-introduced at a later date.

\subsubsection{Committee Stage}

This is the period when the committee assigned to deliberate on a bill examines it more critically. The House and the senate have two types of committees. The first one is the committee of the whole House and second, is the Standing Committees. The House and Senate have many of standing committees. If the committee of the whole house is to discuss a bill, the Deputy Speaker of the House acts as the chairperson. The speaker would leave his seat and sit at the Clerk's seat. The mace too will be taken to the lower table for the committee of the whole House deliberation to commence. In the case of the senate, the Senate president acts as the chairperson of the whole house and thus presides over the committees sittings. When the deputy Speaker or the senate President presides over the committee of the whole house; he stops being addressed as the deputy Speaker or the senate President. Rather, he/she is to be called "Mr. Chairman Sir" or "Chairperson Ma" for the period of the committee session.

As for the standing committees, the chairperson presides over the committee or, in his absence; the deputy stands in for him. Chairmen of standing committees are appointed by the senate President/Speaker of the House. Committees examine all aspects of the bill clause-by-clause and point-by-point. They also organize public hearings on the bill. This may take place at the National Assembly Complex or any other area or location the committee deems appropriate. Any member of the public or expert(s) having interest in the bill may be allowed to attend the public hearing and make contributions to its consideration. A member of the public can make suggestion(s) on any aspect of the bill, but only a member of the committee can propose amendment to the bill. All amendments must be in line with, and relevant to, the principle and the subject matter of the bill as agreed to at the second reading stage.

Sometimes, however, a bill may touch on areas of two or more standing committees. When this happens, the committee with dominant issues will take the bill while others will form sub-committees to consider areas relating to them and report to the main committee. The main committee will collate all suggestions and amendments of the "sub-committees" and report to the House/Senate. For example, all committees are always involved in the "Appropriations Bill" (Budget) but they act as sub-committees to the Appropriations Committee in the House/Senate. In other words, they report back to the Appropriation Committee with their changes or amendments. 


\subsubsection{Committee of the Whole House}

After the committee has concluded its work, it will report to the whole House/Senate. It must ask the House Rules and Business Committee/Senate Committee on rules and Procedures to put the bill on the House/senate calendar (i.e. fix a date and time for the hearing of the committee's report). It is important to note that Committee of the Whole House must also report back to the House/Senate. When it is reporting back, the "Speaker or the senate President" goes back to his former seat and the mace too returned to its original position. Whether it is the Standing Committee or the Committee of the Whole House that is reporting back to the House/Senate, Members of the House/Senate are free to discuss the bill and the amendments of the committee reporting to the House. The House/Senate reviews the report of the committee. When all issues have been discussed and concluded, the bill can go to the next stage: the third reading.

\subsubsection{Third Reading}

During the third reading the house is asked to vote on the bill. Once the bill is passed by the house in which it was introduced, it moves to the other house for consideration. Any amendments which have been made appear in the new version of the bill. After the report of the committee and the deliberation of the committee for the Whole House, a motion may be moved that the bill be read the third time either immediately or at a later date. Generally, no amendment can be entertained after the third reading stage. However, if a member wishes to amend or delete a provision contained in the bill or to introduce a new provision, he must give notice of his intention. "That the bill be re-committed" before the motion for the third reading is moved. If the motion is agreed upon, the House/Senate will dissolve itself into Committee of the Whole House/Senate immediately or at a later date to discuss the amendments. After all necessary amendments, the House/Senate will then proceed on the third reading.

\subsection{Stage Three}

\subsubsection{The Clerk and the Clean Copy of the Bill}

When a bill has been read the third time, a clean printed copy of it, incorporating all amendments will be produced, signed by the Clerk and endorsed by the Speaker/Senate President (Schwartz, 1974). The copy will then be forwarded to the Clerk of the House or senate as the case may be. The copy will be accompanied with a message requiring the concurrence (passage of the bill or agreement) of the receiving chamber (House or Senate). In the other house, the bill goes through the three reading stages again. If the bill originates in the lower house and is amended by the upper house, the amendments then must be sent back to the House of Representatives for consideration. If the lower house does not agree to the amendments then the bill can be referred to the upper house, where the amendments can be reconsidered. In the case of the executive bill, both chambers will just exchange copies of the bill since they both received copies and discussed the bill at the same time. When a bill is sent to either chamber for concurrence, three things may happen:

1) The receiving Chamber may agree with the provisions of the bill and hence pass it or:

2) The Chamber may not agree to some part of the bill and hence make amendments or:

3) The Chamber may not agree with the bill at all and therefore reject it in its entirety. This situation is however rare and has never been witnessed in Nigeria.

In the event of the second situation, the Chamber from which the bill originated may agree with the amendments or recommendations. But if the amendments are not agreeable to the Chamber, then a conference of the two chambers will be constituted to work out any disagreement.

\subsubsection{Conference Committee}

At the conference committee stage, selected members of the committees which considered the bill originally meet and deliberate only on the areas of disagreement between the two chambers. The sitting of the Conference Committee may be open or closed to the public. This will depend on the subject matter under discussion and the view of majority conference committee members. The report of the conference committee is presented in both chambers for consideration. If both chambers approve the bill, all the original papers are sent to the clerk of the chamber where the bill originated. The Clerk puts together all the amendments and produces a clean copy of the bill which is sent to the President for his signature. But if the two Chambers fail to agree after the conference report, a compromise view will have to be sought again through another meeting of the Conference Committee.

\subsection{Stage Four}

\subsubsection{President}

Once the bill has been passed by both houses it is presented to the President. It is the responsibility of the President 
to assent to the new law, which means giving the President's seal of approval. The bill becomes law on the date of the President's assent unless it has a specific clause stating it will only start on a specified date. Once it is law, the bill becomes an act or a statute.

A bill does not become law until the president sings it (Lioyd, 1987). The Clerk of the House/Senate will "enroll" the bill for the president's signature. Enrolment is the production of a clean copy for the assent of the president. The clerk produces the clean copy, certifies it and forwards it to the president. The President has thirty (30) days to sign a bill sent to him/her by the National Assembly. If he disagrees with the provision of the bill or some aspects of it, he can veto by withholding his/her signature. Within the thirty days the president must communicate to the National Assembly his feelings and comments about the bill. The President must state the areas he/she wants to be amended before he signs the bill. If the National Assembly agrees with the President the bill can be withdrawn for deliberation on the amendments suggested by the President.

However, the National Assembly is empowered by the Constitution to over rule the veto of the President (Lawrence, 2005). If, after 30 days, the president refuses to sign the bill and the National Assembly is not in support of the President's amendments, the two Chambers can recall the bill and re-pass it. If the bill is passed in the form it was sent to the President by two thirds (2/3), majorities in both chambers, the bill automatically becomes law even without the signature of the president. This happened in the case of the Niger Delta Development Commission Bill. The two chambers passed the bill into law after the president failed to sign it within the prescribed time for him to do so. The foregoing process of law making is further illustrated by this chart below:

Legisl ative process in both chambers
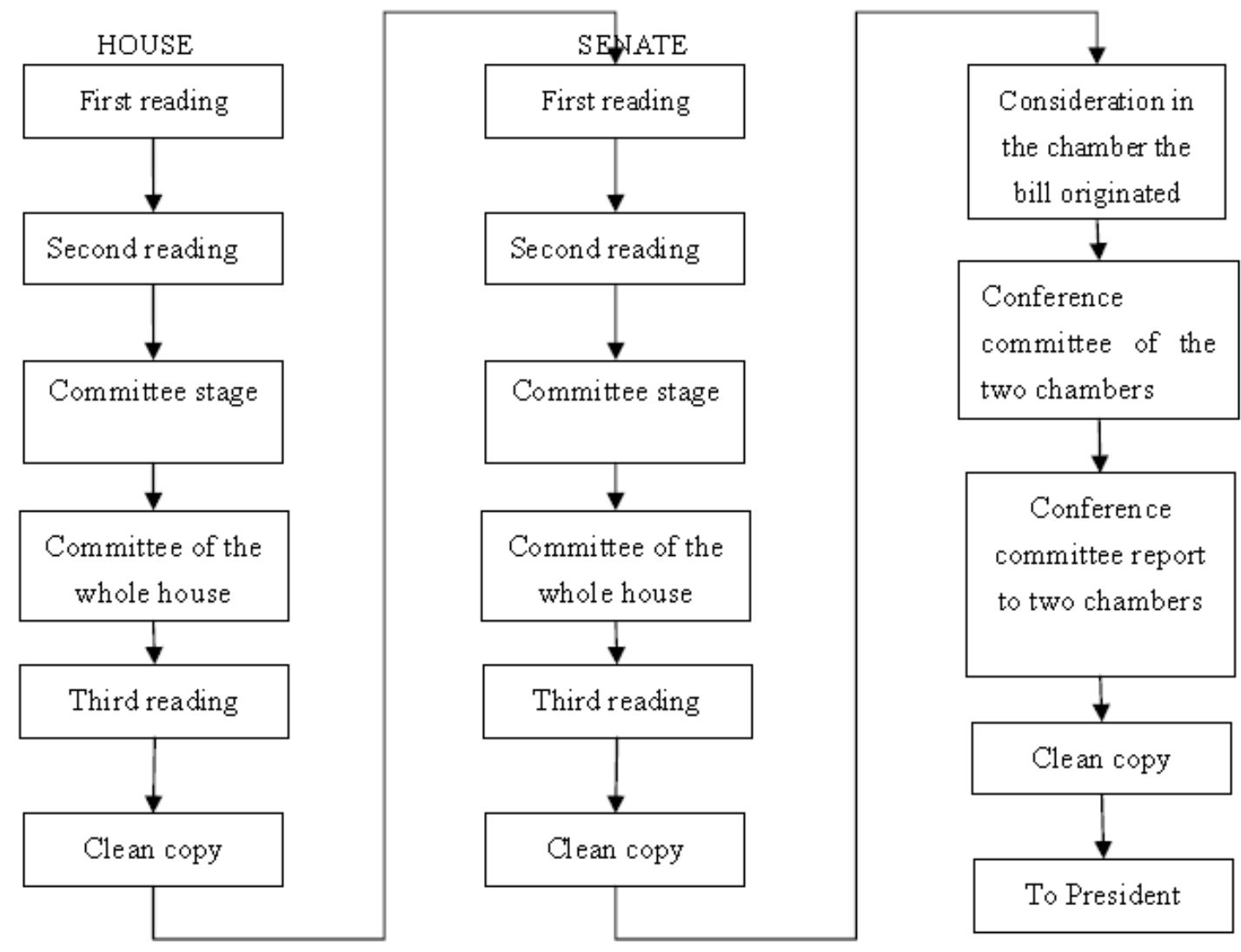

Figure 1. How laws are made in both senate and house of representatives adapted from mbaya, 2009

Figure 1 shows that the bill originated from the House to Senate and to Mr President for his signature. The diagram demonstrates the importance of check and balances between the two chambers; which imply that no bill can be passed into law without the agreement of the two chambers. This means that if the bill originates from House Bill (HB) after following the stages of law making it goes to Senate Bill (SB) for their agreement and passage, then to Mr. President for his endorsement. 


\section{Conclusion}

In conclusion therefore, the National Assembly appears to be more concerned with appropriating generous allowances and budgetary allocations to its members with disregard to public outcry and criticism especially at the beginning of the Fourth Republic. As a result, the business of law making has been abandoned in favour of allegations of falsification of documents, fraud and corruption against the leaders of the National Assembly at the expense of better service delivery. It is therefore, recommended that all bills should be open to public inputs, suggestions, comments, scrutiny and debate to attract public acceptance by Nigerians. By so doing, the electorates can be fully mobilized to recall their legislators that are not performing.

\section{References}

Ali, H. L. (2001). Powers and Limits of the three organs of government in Equal Justice: Human rights monitor. A Quarterly Publication, 3(9).

Almond, G. A., \& Powell, G. B. (1966). Comparative Politics: A Development Approach. Boston: Little Brown.

Brich, A. H. (1983). The British System of Government. London: George Alien and Unwin.

Cardozo, B. N. (1957). An Introduction to Law. Cambridge: Harvard Law Review Association.

Dicey, V. (1965). Law of the Constitution. London: Macmillan.

Egi, J. A. (1997). The Mirror of Government. Ibadan: Rasmed Publications.

Equal Justice. (2001). Human rights monitor. A Quarterly publication, 3(9).

Federal Republic of Nigeria. (1999). Constitution of the Federal Republic of Nigeria. Lagos: Federal government Printer.

Hart, H. L. A. (1961). The Concept of Law. London: Oxford University Press.

Ikelegbe, A. O. (1996). Public Policy Making and Analysis. Benin City: Uri Publishing Ltd.

Jackses, P. (1979). Natural Law. London: Sweet and Maxwell

Jennings, S. I. (1960). The Law and the Constitutions (5th Ed.). London: University of London Press.

Johari, J. C. (2003). Comparative Politics. New Delhi: Sterling.

Lawrence, M. F. (2005). A History of American Law(3rd ed.). New York: Touchstone.

Lioyd, D. (1987). The Idea of Law. Harmondsworth: Penguin.

Mbaya, P. Y. (2007). A Handbook of Development Planning Experience and Perspectives in Nigeria. Maiduguri: Compaq Publishers Limited.

Mbaya, P. Y. (2009). Elements of Comparative Government and Administration. Maiduguri: Mike-B Printing and Publishing.

Oluyede, P. A. (1988). Nigerian Administrative Law. Ibadan: Ibadan University Press.

Padfield, C. (1976). The British Constitution Made Simple, London W. H. Alien.

Pound, R. (1997). Social Control through Law. New Brunswick, NJ: Transaction Publishers.

Schwartz, B. (1974). The Law in America. New York: American Heritage Publishing Co.

Stephen, E., \& Susan, L. (2005). Legal Research: How to Find \& Understand the Law (14th ed.). Berkeley: Nolo.

The 1979 Constitution of the Federal Republic of Nigeria

The 1989 Constitution of the Federal Republic of Nigeria

Ujo, A. A. (2002). Understanding Administrative Law in Nigeria. Kaduna: Awyaotu Enterprises \& Publishers.

William, B. (2006). Introduction to the Law and Legal System of the United States (4th ed.). St. Paul, MN: Thomson West. 